\title{
FILM ANIMASI CERITA DENGAN KONTEKS MULTIBUDAYA UNTUK MENDUKUNG PENGEMBANGAN KEKRITISAN PENALARAN ANAK USIA SD
}

\author{
Yuni Pratiwi \\ Fakultas Sastra Universitas Negeri Malang \\ email: yunipratiwi.fsum@gmail.com
}

\begin{abstract}
Abstrak
Penelitian ini bertujuan menghasilkan enam judul film animasi serial cerita dengan konteks sosial multibudaya untuk mendukung proses pengembangan kemampuan berpikir kritis anak usia SD. Penelitian menggunakan desain penelitian dan pengembangan model R2D2 (recursive, reflective, design, and development) yang dikemukakan oleh Willis. Hasil penelitian sebagai berikut. Pertama, tema film dikembangkan dengan mempertimbangkan pengalaman kehidupan sehari-hari, perkembangan kognitif, dan perkembangan mental. Kedua, tokoh film yakni anak dan orang-orang di sekitar anak dikembangkan dengan latar belakang multietnik. Ketiga, alur cerita dikembangkan dengan mengintegrasikan masalah yang mendorong anak berpikir kritis. Keempat, dialog dikembangkan dengan bahasa sehari-hari. Kelima, aspek audio-visual dikembangkan untuk memperkaya pengalaman anak tentang realitas kehidupan sehari-hari bangsa Indonesia dengan latar masyarakat agraris (pertanian dan peternakan).
\end{abstract}

Kata kunci: film animasi, multibudaya, kekritisan, usia SD

\section{ANIMATED STORY MOVIES WITH MULTICULTURAL CONTEXTS TO SUPPORT THE DEVELOPMENT OF PRIMARY SCHOOL AGED CHILDREN'S CRITICAL REASONING}

\begin{abstract}
This study aims to produce six titles of animated story movies with multicultural social contexts to support the process of the development of primary school aged children's critical thinking skills. This was a research and development study using the R2D2 (recursive, reflective, design, and development) model proposed by Willis. The results of the study were as follows. First, the theme of the movies was developed by taking account of the daily life experience, cognitive development, and mental development. Second, the movie characters, namely children and people around them, were developed with multi-ethnic backgrounds. Third, the plot was developed by integrating the problems encouraging children to think critically. Fourth, the dialogs were developed in daily language. Fifth, the audio-visual aspect was developed to enrich children's experiences about the realities of the daily life of Indonesian people with the background of an agrarian society (agriculture and livestock).
\end{abstract}

Kata kunci: animated movies, multicultural, critical, primary school aged children's

\section{PENDAHULUAN}

Setiap Negara memiliki potensi untuk mengembangkan film animasi cerita anak yang sesuai dengan latar budaya sebagai

landasan pengembangan karakter kebangsaan yang diinginkannya. Wilayah 
negara Indonesia terdiri atas 17.504 pulau dan dihuni oleh 1.128 kelompok etnik (suku bangsa). Kekayaan budaya daerah dapat menjadi sumber inspirasi dalam pengembangan film animasi, khususnya dari segi tema, penokohan, dan latar cerita. Tema-tema dikembangkan dari konteks multibudaya membuka skemata siswa pada fenomena multibudaya di tengah lingkungan hidupnya. Hal ini sesuai dengan sasanti kebangsaan Indonesia, Bhineka Tunggal Ika (berbeda-beda tetapi tetap satu jua). Gagasan ini juga selaras dengan pandangan Marshal (2014:1) yang menyatakan bahwa pada masyarakat multibudaya, budaya dapat diposisikan sebagai sumber kekuatan hidup atau sumberdaya kehidupan yang dapat dikembangkan dan dimanfaatkan secara sadar dalam merespon situasi multibudaya.

Film animasi cerita memiliki posisi yang penting dalam kehidupan anak dan dimanfaatkan untuk memperoleh hiburan maupun pendidikan. Pada saat menonton film animasi cerita, anak-anak tidak hanya mendapatkan hiburan; melainkan juga menyerap berbagai informasi ntuk memperkaya khasanah pengetahuan serta menyerap pesan-pesan pendidikan dari berbagai peristiwa bermakna yang dialami oleh tokoh. Pikiran ini sesuai dengan pendapat Abidin (2015:5-6) bahwa pendidikan anak diorientasikan pada pengembangan insan muda dengan ciri unggul untuk masa yang akan datang. Pendidikan menghasilkan generasi muda yang memiliki kompetensi berpikir, bekerja, berkehidupan sosial, dan menguasai alat-lat untuk bekerja. Pendidikan masa depan membangun generasi yang mampu memecahkan masalah, berpikir metakognisi, dan berpikir kreatif.

Sonhadji (2015:191) mengutip pendapat Rifai dari teori Inkeles mengungkapkan bahwa ciri-ciri manusia modern meliputi (1) terbuka terhadap pembaharuan dan perubahan, (2) sanggup membentuk pendapat secara demokratis, (3) orientasi ke masa kini dan masa depan, (4) perencanaan dan organisasi merupakan bagian integral hidupnya, (5) meyakini kemampuan insani, (6) meyakini keadaan yang dapat diperhitungkan, (7) sadar akan harga diri sendiri/orang lain, (8) meyakini ilmu pengetahuan dan teknologi, dan (9) menganggap ganjaran sebagai hasil dari prestasi (keadilan dalam pembagian. Pemikiran ini selanjutnya digunakan untuk mengembangkan peristiwa-peristiwa dalam film animasi cerita anak usia sekolah dasar (SD) di Indonesia dapat dikembangkan dari ide-ide yang bersumber dari realitas kehidupan.

Cox (76-77) menjelaskan bahwa salah satu tujuan pendidikan multibudaya di sekolah yakni mempromosikan kemajemukan budaya dan hal ini menjadi modal untuk melakukan perubahan sosial ke arah yang lebih positif. Perubahan sosial yang diawali di lingkungan sekolah tersebut dilakukan dengan mengintegrasikan pendidikan multibudaya ke dalam substansi isi teks yang dipelajari, memberikan kesempatan untuk menggunakan berbagai perspektif budaya untuk menemukan pengetahuan reflektif dalam aktivitas belajar yang aktif dan dinamis, dan membangun suatu asumsi bahwa semua peserta didik secara perseorangan maupun kelompok mampu belajar pengetahuan multibudaya. Sekolah yang berakar pada pendekatan mulibudaya menjadi sebuah area untuk merefleksikan berbagai variasi nilai budaya. Sekolah memberikan perhatian yang berimbang pada setiap kelompok budaya dan pada gilirannya sekolah merepresentasikan populasi warga sekolah yang berasal dari berbagai kelompok etnik serta budaya.

Penelitian sejenis dengan judul Pengaruh Penggunaan Media Film Animasi terhadap Motivasi Belajar pada Anak Kelompok B Tk Islam Tunas Melati Yogyakarta yang dilakukan oleh Wiranti (2015) melaporkan bahwa terdapat pengaruh yang signifikan penggunaan media film animasi terhadap 
motivasi belajar pada anak. Selain itu, Hasanah (2012) dalam penelitian dengan judul Model Cerita Fiksi Kontemporer AnakAnak untuk Pengembangan Kemahirwacanaan Siswa Kelas 5 Sekolah Dasar melaporkan tiga temuan yakni, siswa memiliki tanggapan siswa positif terhadap cerita fiksi kontemporer yang digunakan dalam pengembangan kemahirwacanaan, buku-buku fiksi memiliki struktur plot/ narasi tunggal, sederhana, dan linier, memiliki gaya dramatis dan naratif, dan memiliki tema dan nilai yang beraneka ragam, dan fiksi kontemporer untuk anak memberikan sumbangan pada peningkatan literasi. Temuan Hasanah ini diperkuat oleh Andajani, Dawud, dan Pratiwi (2012, 2013) dalam penelitian dengan judul Pengembangan Karya Sastra Berupa Cerita Anak dan Book Talk Berbasis Kekritisan Penalaran bagi Anak Usia SD sebagai Pendukung Indutri Kreatif yang menyimpulkan bahwa siswa sangat antusias merespon cerita anak mengandung masalah, unik, dan tidak ditemukan dalam kehidupan sehari-hari.

Temuan yang disampaikan oleh Wiranti (2015) menjadi landasan utama dari sudut pandang psikologi anak dalam pengembangan film yang akan diproduksi karena film dapat menumbuhkan motivasi belajar secara positif dan signifikan. Penelitian Hasanah (2012) menguatkan gagasan bahwa cerita anak yang dipandang memiliki posisi yang efektif dalam peningkatan literasi anak dapat dimanfaatkan sebagai bahan awal pengembangan film animasi anak. Penelitian ini sekaligus melanjutkan penelian yang dilakukan oleh Andajanai, Dawud, dan Pratiwi $(2012,2013)$

Pada film yang diproduksi dalam penelitian ini keterlibatan anak dalam menonton film ini dipandu dengan booktalk yang menyertai produksi film ini. Booktalk dikembangkan dengan las anbahwa kelas yang sunyi bukanlah kelas yang efektif (Roser dan Martinez, 1995: halaman sampul belakang). Kelas yang efektif ditandai dengan anak-anak yang aktif mengungkapkan respon-respon baik berupa pertanyaan, pernyataan, opini, kritik, harapan, dan keinginan. Booktalk berfungsi sebagai panduan bagi siswa untuk menyampaikan respon-respon terhadap unsur-unsur cerita, visual, dan auditif pada film animasi yang ditontonnya. Book talk dikembangkan untuk menggali respon siswa kritis terhadap tokoh, interaksi antartokoh, alur persitiwa, setting, dan aspek lain dalam film (Staley Library, Milikin University, 2016). Dengan demikian, siswa sekaligus berkesempatan belajar nilai budaya bangsa dan sekaligus mendapatkan kesempatan yang menantang untuk belajar berpikir secara kritis.

\section{METODE}

Posisi penelitian ini merupakan penelitian lanjutan (penelitian tahun pertama menghasilkan skenario film yang ditulis berdasarkan cerita anak hasil penelitian sebelumnya dan draf film). Hal ini dilakukan berdasarkan pendapat Sarumpaet (2010:52) yang menyatakan bahwa penelitian sastra anak (kemudian digunakan sebagai dasar pengembangan film) dilakukan dengan mempertimbangkan sifat-sifat dasar anak misalnya, rasa ingin tahu yang tinggi, kegembiraan, kejujuran, kreativitas, dan daya kritis.

Metode pengembangan didasarkan pada model R2D2 (recursive, reflective, design, and development) yang dikemukakan oleh Wills (1995) dengan sejumlah modifikasi yang disesuaikan dengan kebutuhan, dan secara keseluruhan terbagai dalam enam tahapan kegiatan. Pertama, kegiatan diawali dengan pelaksanaan Focus Group Discussion (FGD) penentuan cerita. Materi yang dibahas meliputi memilih cerpen yang akan difilmkan, dengan aspek kekritisan penalaran, pendidikan nilai karakter, dan relasi multikultural yang bermanfaat anak usia SD. Kedua, kegiatan difokuskan pada workshop penulisan sinopsis cerita untuk film cerita anak 
berbais kekritisan penalaran siswa usia SD. Materi yang dikaji dan dihasilkan dalam kegiatan workshop yang diikuti tim peneliti dengan animator meliputi (1) mengembangkan enam tema dan menetukan keterkaitan antarcerita dalam tujuh seri cerita, (2) menentukan nama tokoh dan karakterisasi, (3) menentukan setting cerita, (4) menentukan alur cerita untuk 6 seri, dan (6) menulis sinopsis cerita untuk 6 seri film. Ketiga, kegiatan dilaksanakan dalam bentuk workshop penulisan shooting script film cerita anak berbasis kekritisan penalaran. Materi yang dibahas mencakup (1) penentuan model shooting script, (2) penulisan shooting script, dan (3) pembahasan shooting script. Keempat, kegiatan FGD dengan materi (1) pembahasan dan penentuan akhir untuk nama tokoh animasi dan visualisasi tokoh, (2) pembahasan dan penentuan visualisasi setting cerita (pewarnaan), dan (3) penentuan dan pembahasan ruang lingkup nilai moral dan tingkat kekritisan yang terkandung dalam cerita serta tokoh terpilih untuk menyampaikannya. Kelima, bertolak dari kegiatan persiapan tersebut selanjutnya dikembangkan film animasi dengan bekerjasama dengan para animator. Keenam, melaksanakan uji produk. Catatan penting dalam uji produk yakni, masukan-masukan diberikan dalam bentuk verbal serta catatan lapangan dan sulit memperoleh data dalam bentuk skor. Pada pandangan ahli dan praktisi (animator) catatan verbal dipandang lebih efektif sebagai pertimbangan untuk memperbaiki produk.

\section{HASIL PENELITIAN DAN PEMBA- HASAN \\ Produk Penelitian}

Penelitian ini menghasilkan 6 judul film yang bersifat serial. Film Persahabatan dalam Keragaman mengisahkan sekelompok peserta didik dari suatu jenjang kelas yang terdiri atas berbagai kelompok etnik di Indonesia. Mereka tinggal di kawasan pertanian/peternakan di pedesaaan dan berusaha keras menjalin persabahabatan meskipun seringkali juga terjadi konflik. Film kedua, Loper Susu mengisahkan seorang anak, Satria yang beretnik Jawa. Satria memutuskan membantu ayahnya, seorang peternak sapi perah, untuk mengantar susu setiap hari Minggu di sela-sela jam bermainnya. Satria berusaha mengendalikan perasaannya antara keinginan membantu ayahnya atau bermain. Pada film ketiga, Pasukan Kebersihan Sekolah mengisahkan kekecewaan seorang gadis kecil, Ulli yang berasal dari Batak, ketika ia di kelas tidak terpilih sebagai ketua persiapan lomba kebersihan di sekolahnya. Akibatnya, ia justru berusaha menggagalkan usaha teman-temannya untuk meraih juara. Pada film keempat, Hadiah Terindah Buat Ayah dikisahkan usaha gigih Yosephine, seorang gadis Papua yang ingin belajar menari Jawa. Respon negatif teman-temannya yang sebagian negatif justru menjadi motivasi bagi Yosephine untuk belajar menari. Film kelima, Senyum untuk Ulli mengisahkan upaya temanteman dari berbagai etnikuntuk untuk meringankan beban orang tua Ulli yang kehilangan pekerjaan karena rombong bakpao terkena razia dan dibawa satpol PP. Ulli yang nakal dan sering mengganggu temannya berbagai kelompok etnik akhirnya sadar bahwa teman-temannya sangat menyayanginya. Pada film keenam, Batik Versus Bluejeans dikisahkan persaingan orientasi budaya dalam kelas saat akan tampil dalam panggung kesenian. Sebagian anggota kelas memilih tampil dengan blue jeans sebagai simbol modernitas dan sebagian lain memilih tampil dengan batik sebagai simbol identitas nasional.

\section{Hasil Uji Produk Hasil Uji dengan Ahli}

Uji ahli melibatkan ahli budaya dan ahli animasi. Berikut adalah catatan yang dihimpun dari kegiatan FGD dengan ahli budaya dapat dilihat pada Tabel 1 . 
Tabel 1. Nilai Budaya pada Produk Awal dan Revisinya

\begin{tabular}{|c|c|c|c|}
\hline & Judul Film & $\begin{array}{c}\text { Nilai Budaya pada Produk } \\
\text { Awal }\end{array}$ & Hasil Revisi Nilai Pendidikan Karakter \\
\hline 1. & $\begin{array}{l}\text { Persabatan } \\
\text { dalam } \\
\text { Keragaman. }\end{array}$ & 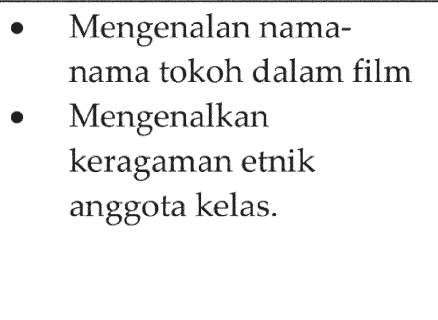 & $\begin{array}{l}\text { - Mengenal nama teman-teman di } \\
\text { kelas yang berbeda etnik dengan baik. } \\
\text { - Mengenal asal teman-teman yang } \\
\text { berbeda etnik dengan baik. } \\
\text { - Mengenal kebiasaan teman yang } \\
\text { berbeda etnik dengan baik. } \\
\text { - Menghormati guru dan teman. }\end{array}$ \\
\hline 2. & Loper Susu & $\begin{array}{l}\text { Mengenalkan dunia } \\
\text { permainan pada anak- } \\
\text { anak. } \\
\text { - Mengenalkan pekerjaan } \\
\text { di bidang peternakan. } \\
\text { Mengenalkan } \\
\text { persabatan dan } \\
\text { masalahnya. }\end{array}$ & $\begin{array}{l}\text { - } \quad \text { Hormat dan mematuhi orang tua. } \\
\text { - } \quad \text { Bertanggungjawab pada tugas } \\
\text { sehari-hari. } \\
\text { Besikap sabar dalam menghadapi } \\
\text { kesulitan. } \\
\text { - Memaafkan kesalahan teman yang } \\
\text { berbeda etnik. }\end{array}$ \\
\hline 3. & $\begin{array}{l}\text { Pasukan } \\
\text { Kebersihan } \\
\text { Sekolah }\end{array}$ & $\begin{array}{l}\text { - Mengenalakan } \\
\text { tanggung jawan } \\
\text { terhadap lingkungan. } \\
\text { - Mengenalkan kerjasama } \\
\text { dalam menjaga } \\
\text { kebersihan kelas. }\end{array}$ & $\begin{array}{l}\text { - Peduli kebersihan lingkungan } \\
\text { Berkerja sama dengan teman antar } \\
\text { etnik dalam melaksanakan tugas. } \\
\text { Bersabar menghadapi kenakalan } \\
\text { teman yang berbeda maupun yang } \\
\text { memiliki kesamaan etnik. } \\
\text { Menghindari amarah dan } \\
\text { kebencian yang berbeda etnik. }\end{array}$ \\
\hline 4. & $\begin{array}{l}\text { Hadiah } \\
\text { Terindah Buat } \\
\text { Ayah }\end{array}$ & $\begin{array}{l}\text { - Mengenalkan seni } \\
\text { budaya Nusantara. } \\
\text { Mengenalkan } \\
\text { kerja/usaha keras untuk } \\
\text { terampil menari. } \\
\text { Menghargai budaya } \\
\text { Nusantara. }\end{array}$ & $\begin{array}{l}\text { - } \quad \text { Mencintai karya seni berbagi etnik. } \\
\text { - } \quad \text { Melajar keras meraih prestasi. } \\
\text { etnik yang kesulitan. } \\
\text { - } \quad \text { Percaya diri tampil di depan } \\
\text { umum. } \\
\text { - Menyanyangi orang tua. }\end{array}$ \\
\hline 5. & $\begin{array}{l}\text { Senyum u } \\
\text { ntuk Ulli }\end{array}$ & $\begin{array}{l}\text { - Memiliki kepedulian } \\
\text { pada nasib orang lain. } \\
\text { Membiasakan untuk } \\
\text { bersikap mau menolong } \\
\text { orang lain. }\end{array}$ & $\begin{array}{l}\text { - Memahami kesulitan teman yang } \\
\text { berbeda etnik } \\
\text { - } \quad \text { Tidak menyepelekan orang miskin. } \\
\text { Berusaha membantu memecahkan } \\
\text { - Tidak punya keinginan balas } \\
\text { - } \quad \text { dendam teman yang berbeda etnik. } \\
\text { - }\end{array}$ \\
\hline 6. & $\begin{array}{l}\text { Batik Versus } \\
\text { Blue Jeans }\end{array}$ & $\begin{array}{l}\text { - Menghargai karya } \\
\text { budaya bangsa. } \\
\text { - Menghargai ide orang } \\
\text { lain. }\end{array}$ & $\begin{array}{l}\text { - Menghargai karya budaya bangsa. } \\
\text { - Menerima budaya lain yang dapat } \\
\text { memperkaya budaya sendiri. } \\
\text { - Mau mendengar ide teman lain } \\
\text { - } \quad \text { Mang berbeda etnik. } \\
\text { - }\end{array}$ \\
\hline
\end{tabular}


Tabel 2. Saran Animator pada Perbaikan Produk

\begin{tabular}{|c|c|c|}
\hline No. & Aspek & Saran Perbaikan \\
\hline 1. & Cerita & $\begin{array}{l}\text { a. Tema cerita sangat bagus, pesan moral/pendidikan sangat } \\
\text { kuat. } \\
\text { b. Alur cerita mengandung stimulan untuk merespon dan } \\
\text { mendorong rasa ingin tahu. } \\
\text { c. Setting sudah spesifik sehingga mendukung pengembangan } \\
\text { cerita. } \\
\text { d. Tokoh-tokoh sudah memiliki karakter yang unik dan memberi } \\
\text { peluang untuk pengembangan cerita. }\end{array}$ \\
\hline 2. & Visual & $\begin{array}{l}\text { a. Colouring terlalu mencolok dan banyak kontras. Hal ini } \\
\text { menimbulkan rasa 'capek' saat menonton. Pilihan warna yang } \\
\text { lebih lembut dan cerah perlu dipertimbangkan. } \\
\text { b. Posture karakter perlu dipertimbangkan lagi untuk anak kelas } \\
\text { awal. } \\
\text { c. Beberapa adegan divisualisasikan dengan gambar yang sama } \\
\text { dengan pesan yang berbeda. Hal ini perlu dicek ulang. } \\
\text { d. Ekspresi tokoh (wajah, sorot mata, gerak bibir) pada beberapa } \\
\text { adegan belum selaras dengan dialog atau perlu diisi ulang } \\
\text { dengan dialog. }\end{array}$ \\
\hline 3. & Auditif & $\begin{array}{l}\text { a. Pada beberapa adegan musik terdengar terlalu keras, sehingga } \\
\text { mengalahkan volume suara pada dialog. } \\
\text { b. Vokal karakter perlu lebih konsisten, terutama pada vocal yang } \\
\text { terkait dengan dialek etnik. } \\
\text { c. Hilangkan kata-kata ekspresi local yang kurang mendidik. }\end{array}$ \\
\hline 4. & Durasi & $\begin{array}{l}\text { a. Jika tayangan ini tanpa jeda, durasi dapat dikurangi. } \\
\text { Intensifkan pada dialog. } \\
\text { b. Pada adegan tertentu, dialog terlalu panjang sehingga } \\
\text { kemungkinan dapat menurunkan fokus. }\end{array}$ \\
\hline
\end{tabular}

\section{Hasil Uji dengan Animator}

Film ini dihasil dengan bekerja dengan tim animator (X Kanopie Production House, Malang). Hasil yang telah diperoleh selanjutnya didiskusikan dalam FGD dengan melibatkan 4 animator yang bekerja untuk production house lain (dalam dan luar negeri). Hasil FGD disajikan dalam ringkasan dapat dilihat pada Tabel 2 .

Berdasarkan masukan dari animator tersebut diketahui elemen film yang perlu diperbaiki mencakup unsur bahasa (kesesuaian antara dialog dengan ekspresi serta perkembangan cerita), visualisasi cerita (adegan berulang, ekspresi yang statis dan tidak sesuai dengan perkembangan cerita), aspek vusial (pewarnaan, keserasian tokoh dengan background/setting, pilihan warna, gambar yang sama berulang hingga tiga kali dan dialog yang menggambarkan pengubahan cearita), aspek auditif (volume latar belakang suara yang terlalu keras sehingga dialog menjadi tidak jelas, ritme musik semakin rumit adegannya harus makin dinamis, penggantian dialog atau monolog panjang yang membuat siswa menurus fokus perhatiannya), teknik animasi (misalnya focusing, angle, durasi, tipe pengambilan gambar), dan durasi (film yang panjang harus dikembangkan dengan plot yang dinamis agar penonton tidak jenuh). Masukan ini menjadi pertimbangan dalam revisi produk yang telah dilakukan. 


\section{Hasil Uji dengan Guru SD}

Dalam kegiatan FGD 22 guru SD, pokok-pokok dibahas terutama difokuskan pada kekritisan penalaran dan muatan aspek budaya. Secara umum, film dapat digunakan untuk meningkatkan kekritisan. Ringkasan respon guru seperti berikut.

1) Film Persahabatan dalam Keanekaragaman dapat digunakan untuk melatih anak mengenali, mengidentifikasi, dan membeda-bedakan fakta. Tema yang dikembangkan berdasarkan keberagaman etnik di Indonesia tersebut mengandung nilai dedaktis bagi anak sebab sejak awal telah dipahamkan bahwa dalam kehidupan sehari-hari anak Indonesia besar kemungkinan bertemu dengan kawan dari berbagai kelompok etnik yang berbeda. Dengan demikian, sejak dini telah ditanamkan benih kebersamaan dalam kehidupan berbangsa.

2) Film Loper Susu mengandung tema bahwa anak-anak harus membiasakan diri untuk kerja keras, betanggung jawab, dan jujur dalam hidup sehari-hari. Tema yang dikembangkan dengan rangkaian pertistiwa sebabakibat tersebut, dapat digunakan untuk pembelajaran penlaran khususnya dalam mengidentifikasi fakta dan mengurutkannya. Dalam urutan tersebut anak juga belajaran penalaran seab-akibat. Tema ini sangat sesuai untuk mata pelajaran Pendidikan Kewarganegaraan $(\mathrm{PKn})$ dan juga mata pelajaran Ilmu Pengetahuan Sosial (IPS). Anak-anak mendapat contoh secara langsung dari perilaku Satria. Lebih dari itu, Satria juga menjadi contoh pembelajaran tentang tanggung jawab dan persahabatan.

3) Film Pasukan Kebersihan Sekolah sangat sesuai untuk penguatan program sekolah adiwiyata. Film yang dikembangkan untuk berlatih memahami unit-unit fakta (peristiwa) yang sala- ing berhubungan ini melatih siswa mengembangkan pola penalaran urutan, sebab-akibat, dan perbandingan. Film ini mengisahkan bahawa sekolah yang bersih, lingkungan yang indah, suasana yang tenang untuk belajar membutuhkan partisipasi siswa untuk mewujudkannya. Ide ini mendukung mata pelajaran Ilmu Pengetahuan Alam (IPA) dan PKn. Perilaku tokoh-tokoh yang sabar, telaten, pekerja keras dalam merawat kelas sebagai bagian dari lingkungan sekolah membantu siswa memperluas wawasan kognitif, sikap, dan perlaku yang baik dalam menjaga lingkungan sekolah.

4) Film Hadiah Terindah untuk Ayah sangat sesuai untuk penguatan perasaan cinta kepada budaya bangsa. Film yang menyajikan fakta yang saling anak mengembangkan penalaran untuk memahami urutan atau proses dan hubungan antarfakta. Tokoh Josephine yang gigih berlatih menari Jawa menunjukkan bahwa kekayaan budaya Nusantara dapat dipelajari oleh anak-anak di seluruh Indonesia. Persabatan, kerja sama, latihan dengan tekun serta sungguh-sungguh menunjukkan bahwa setiap anak dapat berprestasi dan menjadi jaura dalam berbagai bidang kehidupan. Anak-anak perlu dilatih bersikap satria, yakni pemberani, pantang menyerah, jujur, menghargai orang lain, dan tidak sombong. Film ini dapat digunakan sebagai media pembelajaran antara lain untuk mata pelajaran PKn, Ips, Bahasa Indonesia, dan Seni Budaya.

5) Pada film Senyum untuk Ulli, sangat sesuai untuk menanamkan kekritisan penalaran hubungan sebab-akibat dan kretaivitas berpikir. Fakta-fakat yang ditampilkan dalam cerita mendorong siswa berikipir dalam rangkaian urutan sebab akibta. Konflik yang 
dialami salah satu tokoh mendorong tokoh lain berusaha memecahkan masalah secara kritis. Kekritisan penalaran tersebut dapat membantu tokoh memperoleh pemecahan masalah dan kehidupannya menjadi lebih baik. Film ini dapat digunakan media dalam pembelajaran bahasa Indonesia, PKn, IPS. IPA, dan keterampilan.

6) Pada film yang terakhir, Batik versus Blujeans, siswa berlatih memecahkan masalah secara kritis ketika terjadi konflik yang disebabkan perbedaan pandangan terhadap budaya. Masalah ini dipecahkan dengan memadukan unsur-unsur yang baik kedua budaya, yakni budaya global dan budaya lokal. Rangkaian fakta yang disajikan dalam film mendorong peserta didik untuk berpikir kritis ketika terdapat dua kelompok sedang berkonflik dan berusaha mencari pemecahannya.

7) Latihan (pertanyaan) yang dikembangkan memberi kesempatan siswa berpikir berlatih berpikir literal, analitis, dan juga inferensial.

Berdasarkan hasil FGD, dari aspek keritisan dan muatan budaya film ini tidak perlu direvisi. Meskipun demikian, penelitijuga mencatat masukan tambahan misalnya dari segi bahasa (menghilangkan ungkapan daerah yang bermakna kasar, mengurangi durasi yang panjang, dan gambar-gambar sama yang meuncul pada beberapa adegan yang berbeda).

\section{Hasil Uji Lapangan}

Uji lapangan dilakukan pada 3 sekolah dasar dan melibatkan siswa Kelas 1-6. Respon yang disampaikan siswa di beberapa sekolah yang dipilih sebagai kelompok uji coba menunjukkan, pada diri siswa tumbuh sikap empati terhadap perilaku para tokoh dalam film, baik secara individu maupun kelompok. Pada umumnya, siswa memberikan pujian pada sikap dan perilaku tokoh yang gigih mengatasi kesulitan, jujur, suka menolong orang lain, bekerja keras meraih cita-cita, bersikap ramah, dan memiliki toleransi. Sebaliknya, siswa menunjukkan penolakan pada sikap suka mengganggu, malas, curang, menyepelekan, menekan kawan sepermainan. Hal ini menunjukkan bahwa sikap-sikap yang positif penting ditanamkan pada setiap individu tanpa mempedulikan kelompok etniknya. Sikapsikap posoitif tersebut menjadi landasan yang kokoh dalam membangun relasi multibudaya. Sikap yang ditanamkan pada masa anak-anak akan menjadi fondasi tumbuhnya karakter positif dalam konteks masyarakat multietnik serta multibudaya sebab ia sudah terbiasa membangun kebersamaan meski memiliki latar belakang budaya etnik yang beragam.

Berikut adalah contoh kutipan jawaban siswa terhdap film yang ditulis dalam booktalk.

Pertanyaan :

Apa akibat mengotori kelas dengan sampah?

Jawaban :

Tangan menjadi kotor dan sakit perut. (PKS-AC-Kls3-3)

Pertanyaan :

Usaha apa yang dilakukan Josephine agar dapat menari dengan baik?

Jawaban:

Latihan terus.

(HTA-PC-AC-Kls3-4)

Jawaban siswa kelas tiga pada kutipan tersebut menunjukkan bahwa anak-anak sebenarnya memahami isi cerita film tetapi mereka masih merasa kesulitan untuk mengungkapkan dalam bentuk tertulis. Para siswa belum mampu merangkaikan setiap urutan peristiwa yang dipahaminya secara sistematis ke dalam bentuk tertulis. 
a. Pertanyaan :

Tuliskan sebuah nasihat yang perlu disampaikan pada tokoh si Ulli dan kawan-kawannya!

Jawaban :

Jangan suka mengganggu teman!

(PKS-Kelas 1dan 2)

b. Pertanyaan :

Tuliskan sebuah nasihat yang perlu disampaikan pada tokoh Dika dan Deni!

Jawaban :

Jangan mencuri!

(LS-Psn, Kelas 3)

c. Pertanyaan :

Tuliskan sebuah nasihat yang perlu disampaikan pada tokoh si Jago dan kawan-kawannya!

Jawaban :

Jangan suka menyuruh teman!

(KJTMB-Psn C-Kelas 4)

d. Pertanyaan :

Tuliskan sebuah nasihat yang perlu disampaikan pada tokoh Josephine!

Jawaban :

Josephine harus terus latihan menari. (HTA-Psn -Kelas 5)

Kutipan pertanyaan dan jawaban tersebut menunjukkan bahwa siswa mampu menangkap pesan yang disampaikan dan memiliki ketertarikan terhadap pesan yang disampaikan dalam film. Nasihat yang diberikan oleh siswa juga beragam, mulai dari nasihat sederhana hingga yang abstrak, tetapi dengan maksud yang jelas. Pada kutipan tersebut, siswa kelas 3 pun mampu menuliskan nasihat-nasihat untuk Ulli (tokoh dalam film) dan kawankawannya. Nasihat-nasihat yang disampaikan oleh siswa sebenarnya merupakan indikator bahwa pesan budaya dalam film mampu dipahami siswa.

\section{Pembahasan \\ Film Animasi sebagai Media Pembelajar- an Kekritisan Penalaran dalam Konteks Masyarakat Multibudaya}

Karakteristik enam judul film yang telah dihasilkan yakni, (1) memiliki visi budaya untuk mendukung pendidikan nilai multibudaya yang jelas sehingga memiliki sumbangan terhadap pemerolehan pengalaman yang mendukung tumbuhnya budaya yang positif, (2) visi moral sesuai budaya bangsa dan bahkan dapat memberi sumbangan pada pembangunan relasi multibudaya dalam konteks kebangsaan sehingga mendukung pemertahanan budaya bangsa, (3) mendorong anak berpikir kritis melalui pertanyaan latihan yang dikembangkan secara berjenjang sesuai dengan perkembangan kognitif anak, (4) melatih anak menggunakan argumentasi atas setiap opini jawaban yang disampaikannya melalui pertanyaan dan diskusi sesudah menonton film, dan (5) memperluas pengetahuan bahasa yang santun dalam berinteraksi. Produk penelitian ini sesuai dengan hasil riset yang dilakukan Laporta (1957) yang menunjukkan bahwa film sangat mempengaruhi anak, pengaruh itu didapat dari tokoh atau karakter maupun isi film. Film anak juga memberikan kontribusi positif dalam pembentukan mental, intelektual/akademik, sosial dan estetik (Meylan, 1953: 169-175; Sebastian, 2010:5).

Pendidikan kekritisan penalaran ditanamkan melalui aktivitas diskusi setelah menonton film dengan panduan book talk. Book talk dikembangkan untuk memandu dua tahapan diskusi, yakni (1) diskusi yang diarahkan untuk mengapresiasi aspek estetik yang dimaksudkan untuk menggali kembali kesan-kesan terhadap hal-hal yang indah dan menyenangkan dalam film dan (2) diskusi yang difokuskan pada unsur cerita untuk latihan kekritisan. Pertanyaan untuk latihan kekritisan diarahkan pada latihan mengidentifikasi fakta, menglasifikasi fakta, menghubungkan 
antarfakta, membandingkan fakta, menjelaskan urutan peristiwa, menunjukkan hubungan sebab-akibat antarperistiwa, merumuskan sintesis, dan menyampaikan tanggapan kritis. Hal ini selaras dengan pandangan Beach dan Marshall (1991:521) yang menyatakan bahwa dalam pembelajaran melalui film aktivitas yang dapat dikembangkan antara lain menemukan isu atau tema, karakter (tokoh), potensi naratif, konflik, dan juga-tugas-tugas menulis paragraph berdasarkan film yang ditonton. Hal ini selaras dengan publikasi dari Staley Library, Milikin University (2016) menyatalan book talk dikembangkan untuk menggali respon siswa kritis terhadap tokoh, interaksi antartokoh, alur persitiwa, setting, dan aspek lain dalam buku maupun tayangan audio visual lainnya. Hal ini selaras dengan penelitian Hasanah (2012), Andajani, dkk. (2012, 2013), dan Wiranti (2015).

Pada uji lapangan, siswa berusaha terlibat dalam diskusi secara aktif, sebab pertanyaan dalam book talk dikembangkan dengan menghubungkan masalah tokoh dalam film dengan masalah anak dalam kehidupan sehari-hari. Ketika anak-anak berusaha menjawab pertanyaan, jawaban digali dari pengetahuan awal, pengalaman, perasaan, dan harapan-harapan mereka. Dengan demikian, kekritisan pelaran dikembangan dari data dalam film dan dihubungkan dengan kom-

Tabel 3. Aktivitas Pengembangan Kekritisan Penalaran

\begin{tabular}{|c|c|c|}
\hline $\begin{array}{l}\text { Kegiatan untuk Mendorong } \\
\text { Munculnya Respon Estetik }\end{array}$ & $\begin{array}{c}\text { Kegitan untuk Mendorong } \\
\text { Respon Kritis }\end{array}$ & $\begin{array}{c}\text { Kegiatan untuk } \\
\text { Menanamkan Muatan Nilai } \\
\text { Karakter }\end{array}$ \\
\hline $\begin{array}{l}\text { Memilih peristiwa dalam film } \\
\text { yang menarik. }\end{array}$ & Mendaftar nama tokoh. & $\begin{array}{l}\text { Memilih salah satu tokoh } \\
\text { dalam film sebagai sahabat. }\end{array}$ \\
\hline Memilih tokoh yang disukai. & Mendaftarlatar peristiwa. & $\begin{array}{l}\text { Menggambar sahabat dengan } \\
\text { simbol visual tertentu dan } \\
\text { menuliskan alasannya. }\end{array}$ \\
\hline $\begin{array}{l}\text { Memilih peristiwa yang } \\
\text { memiliki kemiripan dengan } \\
\text { pengalaman anak. }\end{array}$ & $\begin{array}{l}\text { Mengelompokkan tokoh } \\
\text { berdasarkan watak. }\end{array}$ & $\begin{array}{l}\text { Menulis surat pribadi untuk } \\
\text { sahabat. }\end{array}$ \\
\hline Menyebutkan keinginan & Mengurutkan peristiwa. & $\begin{array}{l}\text { Membuat rencana kegiatan } \\
\text { bersama sahabat. }\end{array}$ \\
\hline $\begin{array}{l}\text { Menunjukkan peristiwa yang } \\
\text { menyenangkan. }\end{array}$ & $\begin{array}{l}\text { Membandingkan ucapan } \\
\text { tokoh yang berwatak baik } \\
\text { dan tokoh berwtak buruk. }\end{array}$ & $\begin{array}{l}\text { Mengumumkan rencana } \\
\text { kegiatan dengan sahabat. }\end{array}$ \\
\hline $\begin{array}{l}\text { Menunjukkan peristiwa yang } \\
\text { menyedihkan. }\end{array}$ & $\begin{array}{l}\text { Membandingkan perilaku } \\
\text { tokoh yang berwatak baik } \\
\text { dan berwatak buruk. }\end{array}$ & $\begin{array}{l}\text { Menulis naskah fragmen } \\
\text { secara berkelompok dengan } \\
1-2 \text { tokoh dalam film sebagai } \\
\text { tokohnya. }\end{array}$ \\
\hline $\begin{array}{l}\text { Menunjukkan peristiwa yang } \\
\text { mengharukan. }\end{array}$ & $\begin{array}{l}\text { Menceritakan kembali kisah } \\
\text { dalam film. }\end{array}$ & $\begin{array}{l}\text { Bermain peran berdasarkan } \\
\text { naskah yang telah ditulis. }\end{array}$ \\
\hline $\begin{array}{l}\text { Menunjukkan sikap yang } \\
\text { terpuji. }\end{array}$ & $\begin{array}{l}\text { Menghubungkan perilaku } \\
\text { tokoh dengan nasib yang } \\
\text { dialami pada akhir cerita. }\end{array}$ & $\begin{array}{l}\text { Menulis hubungan perilaku } \\
\text { dengan perjalanan nasib } \\
\text { manusia. }\end{array}$ \\
\hline $\begin{array}{l}\text { Menunjukkan sikap yang } \\
\text { tercela. }\end{array}$ & Menilai watak tokoh. & $\begin{array}{l}\text { Menulis daftar sikap buruk } \\
\text { dan sikap baik. }\end{array}$ \\
\hline $\begin{array}{l}\text { Memberi hadiah tokoh yang } \\
\text { disukai. }\end{array}$ & $\begin{array}{l}\text { Menyimpulkan pesan dalam } \\
\text { cerita }\end{array}$ & Mendekarasikan sikap . \\
\hline
\end{tabular}

Film Animasi Cerita dengan Konteks Multibudaya untuk Mendukung Pengembangan ... 
petensi anak. Situasi kelas yang aktif dan responsif ini selaras pendapat Roser dan Martinez (1995).

Pengembangan kekritisan dirancang dan dituangkan dalam book talk yang menyertai produk film. Book talk dapat digunakan oleh guru maupun orang tua untuk mengembangkan aktivitas setelah menonton film. Aktivitas dipilih dan disesuakan dengan jenjang kelas siswa. Berikut adalah desain isi dalam pengembangan book talk dapat dilihat pada Tabel 3.

Catatan penting yang perlu disampaikan berdasarkan uji lapangan yakni, (1) dalam sekali uji pada satu kelas sebaiknya hanya ditayangkan satu judul film; (2) durasi film yang dapat menarik perhatian film secara konsisten yakni 10-12 menit, dan (3) alur cerita yang mengandung konflik, tegangan (suspense), serta kejutan (surprise) dapat menarik perhatian siswa.

\section{Rekomendasi Berdasarkan Produk dan Hasil Uji Produk}

Kebijakan pemerintah dalam pemerataan sebaran penduduk pada wilayah Indonesia dengan strategi transmigrasi dan tuntutan mobilitas manusia dalam pembangunan berdampak munculnya komunitas masyarakat multietnis. Konsekuensinya, mereka akan menjalani kehidupan sebagai komunitas masyarakat multibudaya. Setiap kelompok etnik dalam masyarakat multibudaya memiliki latar belakang kognisi sosial-psikologi yang dibangun dari nilai budaya asal.

Dalam pembelajaran pada kelas dengan siswa multietnis, guru hendaknya selalu menyadari bahwa motivasi untuk hidup bersama-sama secara terusmenerus ditumbuhkembangkan. Kognisi sosial--psikologi yang berbeda, bukan menjadi alasan untuk mengelompokkan perlakuan yang berbeda-beda pada siswa. Film animasi dengan latar masyarakat multibudaya ini dalam jangka panjang dimaksudkan menyiapkan generasi yang memiliki wawasan kognitif_-sosial lebih luas dan lebih siap untuk berkomunikasi komunikasi dunia yang lebih terbuka. Komunikasi budaya dalam konteks nasional tidak cukup jika seseorang hanya memiliki wawasan lokal atau regional. Siswa sejak dini disiapkan mentransformasikan kompetensi kognitif-sosialnya untuk berkomunikasi tidak hanya di lingkungan etnik asalnya, tetapi juga dengan kelompok lain di luar kelompok etniknya. Gagasan ini sesuai dengan pendapat Michael Novak (Lickona, 1991: 50) juga menyatakan bahwa unsur pembentuk sikap bisa dilacak dari tradisi keagamaan, cerita sastra, nasihat kebijakan (sage), dan pandangan hidup tokoh yang mengalir secara turun-temurun secara historis.

Sekolah menjadi sebuah laboratorium budaya yang menyediakan kesempatan pada siswa belajar melakukan adaptasiadaptasi sosial untuk membangun relasi multibudaya yang hormonis dan produktif bagi setiap pihak. Suasana pembelajaran yang kreatif dan menyenangkan sangat diperlukan dalam pembelajaran (Wena, 2009: 160-161). Pembelajaran apresiasi film animasi cerita anak berkonteks multibudaya dapat menumbuhkan motivasi yang tinggi hidup bersama karena kesamaan kepentingan, yakni hidup dalam komunitas bersama yang haronis untuk mewujudkan prestasi masing-masing.

\section{SIMPULAN}

Enam judul film animasi cerita serial yang dihasilkan dalam penelitian dapat dimanfaatkan sebagai media pembelajaran pemahaman kekritisan penalaran. Elemen kekritisan yang dikembangkan mencakup kemampuan menggunakan pola-pola penalaran misalnya memahami dan mengidentifikasi fakta, menganaisis dan membedakan fakta, menganalisis dan membandingkan fakta, mengurutkan peristiwa, menyimpulkan, dan menunjukkan keunikan kehidupan masyarakat multibudaya. Latihan kekritisan penalar- 
an dikembangkan atau dipandu melalui book talk.

Dalam pandangan ahli, animator, praktisi (guru SD), dan juga hasil catatan pada saat pelaksanaan uji lapangan diperoleh simpulan (1) tema film dikembangkan dari kehidupan sehari-hari anak; (2) tokoh yang ditampilan adalah anak-anak dan orang-orang di sekitar anak; (3) peristiwa dikembangkan dengan mengintegrasikan suatu maslah yang mendorong anak untuk mencari pemecahan secara kritis dengan pola penalaran tertentu (misalnya, urutan, sebab-akibat, perbandingan, hubungan), (3) setting dipilih dari setting fisik dan sosial yang khas (dalam penelitian ini dipilih setting pedesaan dengan latar pertanian dan peternakan) dengan alasan siswa akan mengenali setting geografis dan budaya Indonesia yang menarik; (4) bahasa Indonesia yang digunakan untuk mengembangkan dialog memperhatikan kemampuan dan nilai kesantunan bahasa anak; (5) aspek audio-visual harus dinamis agar tidak membosankan, (6) durasi film sekitar 10-12 menit.

\section{UCAPAN TERIMA KASIH}

Penerbitan artikel hasil penelitian ini dapat dilakukan karena dukungan dana dari Direktorat Penelitian dan Pengabdian kepada Masyarakat, Direktorat Riset dan Pendidikan Tinggi, Kemeterian Riset dan Pendidikan Tinggi; izin dari pimpinan Universitas Negeri Malang, dan usaha keras tim redaksi Jurnal Litera Fakultas Bahasa dan Seni, Universitas Negeri Yogyakarta yang mengupayakan penerbitan artikel. Penulis menyampaikan penghargaan dan terima kasih, teriring harapan arikel ini dapat memberikan sumbangan pengembangan ilmu yang bermanfaat bagi semua pihak.

\section{DAFTAR PUSTAKA}

Abidin, Yunus. 2015. Pembelajaran Multiliterasi. Bandung: Refika Aditama.
Andajani, Kusubakti; Dawud, Pratiwi, Pratiwi. 2012. "Pengembangan Karya Sastra Berupa Cerita Anak dan Book Talk Berbasis Kekritisan Penalaran bagi Anak Usia SD sebagai Pendukung Industri Kreatif". Laporan Penelitian. Tidak Diterbitkan. Malang: Lembaga Penelitian dan Pengabdian kepada Masyarakat.

Andajani, Kusubakti; Dawud, Pratiwi, Pratiwi. 2013. "Pengembangan Karya Sastra Berupa Cerita Anak dan Book Talk Berbasis Kekritisan Penalaran bagi Anak Usia SD sebagai Pendukung Indutri Kreatif". Laporan Penelitian. Tidak Ditebitkan. Malang: Lembaga Penelitian dan Pengabdian kepada Masyarakat.

Beach, R.W. \& Marshall, JD. 1991. Teaching Literature in Secondary School. San Diego: Harcourt Breat Javanovich.

Cox, Carole. 1999. Teaching Language Art: A Student-and Response-Centered Classroom. Boston: Allyn an Bacon.

Hasanah, Muakibatul. 2012. "Model Cerita Fiksi Kontemporer Anak-Anak untuk Pengembangan Kemahirwacanaan Siswa Kelas 5 Sekolah Dasar". Jurnal Litera. Vol 11, No 1. Fakultas Bahasa dan Seni, UNY.

Http//www, The Blog of Maharddhika Zifana, 2009. Model Role Playing dalam Pembelajaran.

Laporta, Raffaelo. Cinema ed eta evolutiva. The cinema and the age of development. Florence, La Nuova Italia, 1957, 188 p. "Educatori Antichi e Moderni" series, 153.

Lickona, T. 1991, Educating for Character: How Our Schools Can Teach Respect and Responsibility. New York: Bantam Books.

Marshall, Katherine. 2014. Identity: Social Harmony in Plural, Multicultural Societies - What have we learned?.(Online), (https://berkley.georgetown.edu.). Diakses 23 September 2016. 
Meylan, Luis M. Le cinema et 1' Education morale. The cinema and moral education. Actes du Congres international sur la presse periodique, cinematographie et radio pour enfants, Milan, 19-23 March 1952, Milan, A. Giuffre, 1953, p. 169-175.

Roser, Nancy L dan Martinez Miriam G (Ed.). 1995. Booktalk and Beyond Children and Teachers Respond to Literature. Amazon: Intl Reading Assn.

Sarumpaet, Riris K.T. 2010. Pedoman Penelitian Sastra Anak. Jakarta: Pustaka Obor Indonesia.

Sebastian, T, Wilson. 2010. 'A Study to Impact of Computer Animation on Children in Three Cities of Kerala (Calicut, Cochin, \& TVM)". Thesis submitted to the University of Calicut for the Degree of Doctor of Philosopy in Journalism and Mass Communication.(Online), (http://shodhganga. inflibnet.ac.in/hendle/10603/3286). Diakses 20 Agustus 2014.

Sonhadji, Ahmad. 2015. Membangun Peradaban Bangsa dalam Perspektif Multikultural. Malang: UM Press.

Staley Library. 2016. Childrens-Literature/ Booktalks. Http://millikin.libguides. com). 23 September 2016

Wena, Made. 2009. Strategi Pembelajaran Inovatif Kontemporer. Jakarta: Bumi Aksara.

Willis, Jerry. 1995. "A Recursive, Reflective Instructional Model Based on Constructivism-Interpretive Theory". Educational Technology. 35(6) 5-23.

Wiranti, Wahyu Ika. 2015. Pengaruh Penggunaan Media Film Animasi terhadap Motivasi Belajar pada Anak Kelompok B Tk Islam Tunas Melati Yogyakarta. S1 thesis, PAUD. (Online), (http://eprints. uny.ac.id/28903). 21 September 2016. 